\title{
Evaluation of Digestible lysine levels in diets with high energy density for finishing pigs
}

\author{
Evaluación de niveles de lisina digestible en dietas con alta \\ densidad energética para cerdos en finalización
}

\author{
Janeth Colina R, ${ }^{1 *}$ Ph.D, Miguel Díaz $\mathrm{E}^{2}{ }^{2}$ Ing. Agrónomo, \\ Luis Manzanilla $M{ }^{2}$ Ing. Agrónomo, Humberto Araque $M,{ }^{2}$ M.Sc, \\ Gonzálo Martínez G, ${ }^{2}$ Ph.D, Mario Rossini V, ${ }^{3}$ M.Sc, Nancy Jerez-Timaure, ${ }^{4}$ Ph.D.
}

\begin{abstract}
${ }^{1}$ Universidad Central de Venezuela. Facultad de Ciencias Veterinarias. Cátedra de Producción Animal. Final prolongación de la Av. 19 de Abril con Av. Casanova Godoy. Ofic. 15. Maracay, estado Aragua. 2101. Venezuela. ${ }^{2}$ Universidad Central de Venezuela. Facultad de Agronomía, Instituto de Producción Animal. Final prolongación de la Av. 19 de Abril con Av. Casanova Godoy Edif. 1. Maracay, estado Aragua. 2101. '3niversidad Central de Venezuela. Facultad de Ciencias Veterinarias. Laboratorio de Patología Clínica. Final prolongación de la Av. 19 de Abril con Av. Casanova Godoy. Edif. 2. Maracay, estado Aragua. 2101. Venezuela. ${ }^{4}$ Universidad del Zulia. Facultad de Agronomía, Departamento de Zootecnia. Av. Goajira. Edif. 1. Maracaibo, estado Zulia. 4005. Venezuela. *Correspondencia: janeth. colina@ucv.ve
\end{abstract}

Received: May 2014; Accepted: December 2014.

\begin{abstract}
Objective. To evaluate the effects of different levels of digestible lysine in diets with high energy density on productive performance and carcass characteristics of finishing pigs. Materials and Methods. Seventy crossbred barrows (initial body weight of $83.36 \mathrm{~kg}$ ) were used and allotted in a randomized block design with five treatments, seven replications and two pigs per experimental unit. Pigs were fed ad libitum with diets containing $3.5 \mathrm{kcal} / \mathrm{kg}$ of $\mathrm{ME}$ and five levels of digestible lysine $(0.46,0.52,0.58,0.64$ and $0.70 \%)$ during four weeks. Final live weight (FLW), daily feed intake (DFI), daily weight gain (DWG), feed conversion (FC), daily lysine intake (DLI), and the amount of lysine per body weight gain (DLI/DWG), were evaluated. At the end of the experiment, blood samples were taken from each pig to determine urea nitrogen concentration (UN) in serum and slaughtered to evaluate quantitative and qualitative carcass characteristics. Results. The FLW increased linearly $(p<0.05)$.There were no differences among treatments for DFI, DWG, FC, carcass characteristics and UN. The DLI and DLI/DWG varied significantly $(p<0.001)$ and increased linearly $(p<0.001)$ with each lysine level. Pigs that consumed the limiting diet in lysine $(0.46 \%)$ showed less DLI and DLI/DWG $(p<0.001)$ than pigs fed the other diets. Conclusions. The amount of DLI/DWG increased with the evaluated levels of digestible lysine in diets with high energy density, without effects on productive performance and carcass characteristics of finishing pigs.
\end{abstract}

Key words: Amino acids, backfat thickness, barrows, growth, pork, urea (Source: Agrovoc). 


\section{RESUMEN}

Objetivo. Evaluar los efectos de diferentes niveles de lisina digestible en dietas con alta densidad energética sobre el desempeño productivo y características de la canal de cerdos en finalización. Materiales y métodos. Se utilizaron 70 cerdos (peso inicial de $83.36 \mathrm{~kg}$ ) mestizos castrados, distribuidos en un diseño de bloques al azar con cinco tratamientos, siete repeticiones y dos cerdos por unidad experimental. Los cerdos fueron alimentados ad libitum con dietas que contenían 3.5 $\mathrm{Mcal} / \mathrm{kg}$ de energía metabolizable y cinco niveles de lisina digestible $(0.46,0.52,0.58,0.64$ y $0.70 \%)$ durante cuatro semanas. Se evaluaron: peso vivo final (PVF), consumo diario de alimento (CDA), ganancia diaria de peso (GDP), conversión de alimento (CA), consumo diario de lisina (CDLis) y la cantidad de lisina por peso ganado (CDLis/GDP). Al final de experimento, se extrajeron muestras de sangre de todos los cerdos para determinar la concentración de nitrógeno ureico (NU) en suero sanguíneo y luego se sacrificaron para evaluar las características cualitativas y cuantitativas de la canal. Resultados. No se observaron diferencias significativas entre tratamientos para CDA, GDP, CA, características de la canal y NU. El PVF incrementó linealmente $(p<0.05)$. El CDLis y la CDLis/ GDP variaron significativamente $(p<0.001)$ e incrementaron linealmente $(p<0.001)$ con cada nivel de lisina. Los cerdos que consumieron la dieta limitante en lisina $(0.46 \%)$ mostraron menor consumo y CDLis/GDP $(p<0.001)$ que los cerdos alimentados con las otras dietas. Conclusiones. Los niveles de lisina digestible evaluados en dietas con alta densidad energética aumentan la CDLis/GDP, sin efectos sobre el desempeño productivo y las características de la canal de los cerdos en finalización.

Palabras clave: Aminoácidos, carne de cerdo, cerdo castrado, crecimiento, tocino magro, urea (Fuente: Agrovoc).

\section{INTRODUCTION}

Modern pork production is based on using breeds whose optimal performance is determined, principally, by the quality of the diet. Genetic improvement has led to a selection of pigs with greater protein deposition and muscle development (1), which deserves to evaluate amino acids requirements for adequate diet formulation. Also, the amount of an amino acid and energy density in these diets determine the deposition of protein and fat in the pork carcass (2). Lysine is the first limiting amino acid in pig diets, and is used as a reference in the formulation, considering the recommended levels of standardized digestible lysine to estimate the requirements of other essential amino acids and guarantee optimum growth and yield in lean meat (3-5). For finishing pigs between 80 and $120 \mathrm{~kg}$ of weight, $0.52 \%$ dietary digestible lysine is recommended (6).

Additionally, feed intake is determined by dietary energy density (6), and it is therefore appropriate to adjust the proportion of amino acids if the energy density or feed intake changes (7). Previous studies in temperate climates (8-11) have evaluated the growth and carcass characteristics of pigs in response to different levels of lysine in high energy density diets without evidence of negative effects on these characteristics. On the other hand, it has been demonstrated that high energy density diets limiting in lysine do not have deleterious effects

\section{INTRODUCCIÓN}

La producción porcina moderna se sustenta en la utilización de líneas genéticas cuyos óptimos rendimientos están determinados, principalmente, por la calidad de la dieta. El mejoramiento genético ha conducido a la selección de cerdos con mayor deposición de proteína y desarrollo de tejido muscular (1), lo que amerita evaluar las necesidades de los aminoácidos en las dietas para formularlas adecuadamente. Además, la cantidad de un aminoácido y la densidad energética en esas dietas determinan la deposición de proteína y grasa en la canal porcina (2). La lisina es el primer aminoácido limitante en dietas para cerdos, y se utiliza como referencia en la formulación considerando los valores recomendados de lisina digestible estandarizada para estimar los requerimientos de los otros aminoácidos esenciales y garantizar un óptimo crecimiento y rendimiento en carne magra (3-5). Se recomienda $0.52 \%$ de lisina digestible en la dieta de cerdos en etapa de finalización entre 80 y $120 \mathrm{~kg}$ de peso (6).

Adicionalmente, el consumo de alimento está determinado por la densidad energética de la dieta (6), por lo que es apropiado ajustar la proporción de los aminoácidos si la densidad energética o el consumo de alimento varían (7). Estudios previos en condiciones de clima templado (8-11), han evaluado el crecimiento y las características de la canal de cerdos en respuesta a diferentes niveles de lisina en dietas 
on growth but increase the fat content in the carcass of finishing pigs (12), while pigs fed during this phase with diets low in lysine and energy have increased deposition of back and intramuscular fat in the carcass (13).

In Venezuela, studies have been conducted to evaluate the carcass characteristics of pigs $(14,15)$ without considering the effect of digestible lysine on that. In this sense, it is necessary to investigate this highly relevant point in the tropic, since climatic conditions affect the requirements of amino acids and the productive performance of pigs (4) while genetic factors and variations between animals also influence the results obtained (2).

The objective of this study was to evaluate the effects of different levels of digestible lysine in diets with a high energy density on the productive performance and carcass characteristics of finishing pigs.

\section{MATERIALS AND METHODS}

Bioethical aspects. The Bioethics Committee of the Faculty of Veterinary Sciences at the Universidad Central de Venezuela (FCV-UCV) endorsed this study, which was within established protocol when using experimental animals.

Study location. The study was performed in the Laboratory of the Swine Section of the Institute of Animal Production in the Agronomy Faculty at the Universidad Central de Venezuela (UCV) in Maracay, Aragua State. The climatic conditions of the area: (67036'36" Iongitude, $10^{\circ} 16^{\prime} 20^{\prime \prime}$ latitude, and 443 meters above sea level), average temperature of $25.1^{\circ} \mathrm{C}$ and average annual rainfall of $1.063 \mathrm{~mm}$. Two experimental barns and 35 pens were used. In one barn 20 pens were used ( $4 \mathrm{~m}^{2}$ each), with a concrete floor and separated by walls; and in the second barn 15 pens were used $\left(4.2 \mathrm{~m}^{2}\right.$ each), with half solid flooring and half drainage, with concrete divisions. Both barns had aluminum sheeting roofs and natural light. Each pen had a fixed self feeder and a stainless steel nipple waterer to provide feed and water ad libitum, respectively.

Animals. Seventy crossbred barrows (Yorkshire $\times$ Landrace $\times$ Duroc) with an average initial body weight of $83.36 \mathrm{~kg}$, from a commercial farm were used. Pigs were randomly allotted, two per pen, to one of five experimental diets (treatments) for four weeks.

Diets. Table 1 shows the ingredients and chemical composition of the experimental diets, formulated to obtain five different levels con alta densidad energética sin evidencia de efectos negativos sobre estas características. Por otra parte, se ha demostrado que el consumo de dietas con alta densidad energética y limitantes en lisina no tiene efectos deletéreos sobre el crecimiento pero aumenta el contenido de grasa en la canal de cerdos en etapa de finalización (12), mientras que los cerdos alimentados en esta etapa con dietas de bajo contenido de lisina y energía han resultado en incrementos en la deposición de la grasa dorsal e intramuscular en las canales obtenidas (13).

En Venezuela se han realizado estudios para evaluar las características de las canales porcinas $(14,15)$ sin considerar el efecto del contenido de lisina digestible sobre las mismas. En tal sentido, en condiciones tropicales se hace necesario indagar sobre este aspecto, lo cual es de gran relevancia ya que las condiciones climáticas afectan los requerimientos de los aminoácidos y el desempeño productivo de los cerdos (4) mientras que los factores genéticos y las variaciones entre animales también influyen en la respuesta obtenida (2).

El objetivo de este estudio fue evaluar los efectos de diferentes niveles de lisina digestible en dietas con alta densidad energética sobre el desempeño productivo y características de la canal de cerdos en finalización.

\section{MATERIALES Y MÉTODOS}

Aspectos de bioética. El Comité de Bioética de la Facultad de Ciencias Veterinarias de la Universidad Central de Venezuela (FCV-UCV) avaló la ejecución de este estudio, por ajustarse a los procedimientos establecidos en el protocolo para uso de animales en investigación.

Sitio de estudio. El estudio se realizó en el Laboratorio de la Sección de Porcinos del Instituto de Producción Animal en la Facultad de Agronomía de la Universidad Central de Venezuela (UCV) en Maracay, Estado Aragua. Las condiciones climáticas de la zona (67036'36" longitud, $10^{\circ} 16^{\prime} 20^{\prime \prime}$ latitud, y 443 m.s.n.m), son temperatura media de $25.1^{\circ} \mathrm{C}$ y pluviosidad promedio anual de $1063 \mathrm{~mm}$. Se dispuso de dos galpones experimentales y 35 corrales. En un galpón se utilizaron 20 corrales ( $4 \mathrm{~m}^{2}$ cada uno), con piso de concreto y separados por paredes; y en el segundo galpón se utilizaron 15 corrales (4.2 $\mathrm{m}^{2}$ cada uno), piso mitad sólido y mitad con drenaje, con divisiones de concreto. Ambos galpones con techo de láminas de aluminio e incidencia de luz diurna. Cada corral estaba provisto de un comedero fijo y un bebedero tipo 
of digestible lysine $(0.46 ; 0.52 ; 0.58 ; 0.64$ y $0.70 \%)$. The increase in each level of digestible lysine was obtained by adjusting the amount of corn, soybean meal and synthetic lysine in each one of the diets, which contained $5 \%$ raw palm oil, obtaining $3.50 \mathrm{Mcal} / \mathrm{kg}$ of metabolizable energy (ME). The content of the rest of the nutrients was adjusted according to the nutritional needs (6). The chemical composition of the ingredients used (corn and soybean meal) and the experimental diets was determined by analyzing the dry matter (DM: $\left.105^{\circ} \mathrm{C} / 24 \mathrm{~h}\right)$ and crude protein $(\mathrm{N} \mathrm{Kjeldahl} \times 6.25$ ) according to the procedures described (16). The content of lysine in experimental diets was determined using near infrared spectroscopy (NIRS).

Table 1. Experimental diets.

\begin{tabular}{|c|c|c|c|c|c|}
\hline Ingredients, $\%$ & & & & & \\
\hline Yellow corn meal & 81.87 & 81.87 & 81.85 & 81.90 & 81.92 \\
\hline Soybean meal & 9.40 & 9.30 & 9.24 & 9.10 & 9.00 \\
\hline Raw palm oil & 5.00 & 5.00 & 5.00 & 5.00 & 5.00 \\
\hline Wheat bran & 1.50 & 1.50 & 1.50 & 1.50 & 1.50 \\
\hline Calcium carbonate, $32 \%$ & 1.15 & 1.15 & 1.15 & 1.15 & 1.15 \\
\hline Phosphate, $18 / 20$ & 0.27 & 0.27 & 0.27 & 0.27 & 0.27 \\
\hline Vitamins and minerals ${ }^{a}$ & 0.50 & 0.50 & 0.50 & 0.50 & 0.50 \\
\hline Salt & 0.30 & 0.30 & 0.30 & 0.30 & 0.30 \\
\hline L-Lysine $\mathrm{HCl}$ & 0.02 & 0.11 & 0.19 & 0.28 & 0.36 \\
\hline \multicolumn{6}{|l|}{ Chemical composition } \\
\hline Metabolizable energy, Mcal/kg ${ }^{b}$ & 3.50 & 3.50 & 3.50 & 3.50 & 3.50 \\
\hline Total protein, $\%^{c}$ & 11.57 & 11.56 & 11.61 & 11.63 & 11.67 \\
\hline Available phosphorus, $\%^{\mathrm{b}}$ & 0.15 & 0.15 & 0.15 & 0.15 & 0.15 \\
\hline Total lysine, $\%^{c}$ & 0.50 & 0.57 & 0.63 & 0.69 & 0.76 \\
\hline Digestible lysine, $\%$ & 0.46 & 0.52 & 0.58 & 0.64 & 0.70 \\
\hline Calcium, $\%{ }^{\mathrm{b}}$ & 0.45 & 0.45 & 0.45 & 0.45 & 0.45 \\
\hline
\end{tabular}

Provides the following quantities per $\mathrm{kg}$ of diet according to the manufacturer: Vitamin A, 7000 UI; Vitamin D3, 2000, Vitamin E, 5UI; Vitamin K3, 2 mg; Thiamine, $1.5 \mathrm{mg}$; Riboflavin, $4 \mathrm{mg}$; Pyridoxine, $3 \mathrm{mg}$; Vitamin C, $70 \mathrm{mg}$; nicotinic acid, $20 \mathrm{mg}$; pantothenic acid, $8 \mathrm{mg}$; choline, $130 \mathrm{mg}$; Antioxidant, 50 $\mathrm{mg}$; Se, $0.23 \mathrm{mg} ; \mathrm{Mn}, 50 \mathrm{mg}$; Zn, 60mg; Cu. 40 mg; Fe, 80 mg; Co, $0.10 \mathrm{mg}$ Calculated values

c Analyzed values

Productive performance variables. The pigs were weighed weekly using an electronic scale (TruTest ${ }^{\circledR}$ Speedrite, Series EC 2000) with a $1500 \mathrm{~kg}$ capacity. The daily feed intake (DFI) was determined through weighing and recording the feed placed in the feeders minus the feed not consumed weekly by each experimental unit. The average initial live weight (ILW) and the final live weight (FLW) of pigs in each experimental unit, were used to calculate the daily weight gain (DWG) and the feed conversion (FC= DFI/DWG) was estimated. Additionally, the daily intake of lysine (DLI) was estimated considering the content of lysine obtained through analysis of each diet formulated and the intake of lysine for each kilogram of live weight gained (DLI/DWG) according to what suggested in other studies $(7,10)$. chupón de acero inoxidable, para suministro de alimento y agua ad libitum, respectivamente.

Animales. Se utilizaron 70 cerdos mestizos (Yorkshire $\times$ Landrace $\times$ Duroc) castrados, con peso promedio inicial de $83.36 \mathrm{~kg}$, provenientes de una granja comercial. Los cerdos fueron alojados al azar, dos por corral y asignados a una de cada cinco dietas experimentales (tratamientos), durante cuatro semanas.

Dietas. En la tabla 1 se muestran los ingredientes y composición química de las dietas experimentales, formuladas para obtener cinco diferentes niveles de lisina digestible $(0.46 ; 0.52 ; 0.58 ; 0.64$ y $0.70 \%$ ). El incremento en cada nivel de lisina digestible se obtuvo ajustando la cantidad de maíz, soya y lisina sintética en cada una de las dietas, las cuales contenían $5 \%$ de aceite crudo de palma, obteniéndose $3.50 \mathrm{Mcal} / \mathrm{kg}$ de energía metabolizable (EM). El contenido del resto de los nutrientes se ajustó de acuerdo con las necesidades nutricionales (6). Las composición química de los ingredientes utilizados (maíz y soya) y las dietas experimentales se determinó mediante análisis de la materia seca $\left(\mathrm{MS}: 105^{\circ} \mathrm{C} / 24 \mathrm{~h}\right.$ ) y proteína cruda ( $\mathrm{N} \mathrm{Kjeldahl} \times 6.25)$ de acuerdo a los procedimientos descritos (16). El contenido de lisina en las dietas experimentales se determinó mediante espectroscopia en infrarrojo cercano (NIRS).

Variables de desempeño productivo. LoS cerdos fueron pesados semanalmente utilizando una báscula electrónica (Tru-Test ${ }^{\circledR}$ Speedrite, Serie EC 2000) con capacidad para $1500 \mathrm{~kg}$. El consumo diario de alimento (CDA) se determinó a través del pesaje y registro del alimento colocado en los comederos menos el alimento no consumido semanalmente para cada unidad experimental. El peso vivo inicial (PVI) y final (PVF) promedio de los cerdos en cada unidad experimental permitieron calcular la GDP y se estimó la conversión de alimento $(C A=C D A$ / GDP). Adicionalmente, se estimó el consumo diario de lisina (CDLis) considerando el contenido de lisina obtenido mediante análisis de cada dieta formulada y el consumo de lisina por cada kilogramo de peso vivo ganado (CDLis/GDP) de acuerdo con lo señalado en otros estudios $(7,10)$.

Determinación de nitrógeno ureico. Para determinar la concentración de nitrógeno ureico (NU) en suero sanguíneo, se extrajeron muestras de sangre a todos los cerdos, entre las 08:00 y 10:00 h el último día del experimento, para ello, se consideraron las normas de bioética para la utilización de animales con fines experimentales en Venezuela (17). 
Determining urea nitrogen. To determine the concentration of serum urea nitrogen (UN), blood samples were taken from each pig between 08:00 y 10:00 h the last day of the experiment considering the bioethical standards for using experimental animals in Venezuela (17).

Blood samples were extracted in duplicate by puncture of external jugular vein using $18 \mathrm{G} \mathrm{x}$ $11 / 2^{\prime \prime}$ needles and $5 \mathrm{~mL}$ vacuum tubes (Gel Clot Activator, Vacuum Diagnostics, Zhejiang, China). The samples were transported to the Laboratory of Clinical Pathology of the FCV-UCV, where the serum was separated by centrifuge at $1.200 \mathrm{~g}$ for 20 min at $4^{\circ} \mathrm{C}$ within $8 \mathrm{~h}$ after collection and were conserved in $2 \mathrm{~mL}$ aliquots at $-20^{\circ} \mathrm{C}$ until analysis. The analysis was done in duplicate using a quantitative kinetic determination kit (Chemroy ${ }^{\circledR}$, procedure CR245, Texas, U.S.A.) and the concentration of UN in serum was expressed in $\mathrm{mg} / \mathrm{dL}$.

Carcass evaluation. When the pigs reached slaughter weight (an average of $102.81 \mathrm{~kg}$ ), were subjected to a $24 \mathrm{~h}$ period of fasting and were moved to the commercial slaughter facility; after $6 \mathrm{~h}$ of rest, the pigs were electrically stunned and slaughtered by exsanguination, according to the procedures established in the code for hygiene practices in Venezuela (18). The hot carcass weight was recorded ( $\mathrm{HCW}$, with the head and feet), carcass yield (CY) was calculated, and the carcass were later refrigerated $\left(4-6^{\circ} \mathrm{C}\right)$ for $16-24$ $\mathrm{h}$. After this period the head was removed and the carcass was cut longitudinally into two equal halves, allowing the quantitative characteristics to be evaluated. The backfat thickness (BFT) was measured with a metric ruler in three places: opposite to the first rib, last rib, and last lumbar vertebra, respectively, obtaining an average of the three measurements. A transverse cut between the $10^{\text {th }}$ and $11^{\text {th }}$ intercostal space was performed to measure the Longissimus dorsi muscle area (LDMA) using a grid; the depth of the back fat (BFD) that covers the LDMA was measured with a metric ruler in three positions of the muscle area $(1 / 4,1 / 2$, and $3 / 4)$. The values obtained of the LDMA and the BFD were used to calculate the lean carcass yield (LCY) using prediction equations $(6,19)$.

The qualitative characteristics evaluated in the carcass were $\mathrm{pH}$, temperature and water holding capacity (WHC). The $\mathrm{pH}$ and the temperature of the carcass were measured in the semimembranious muscle at $45 \min \left(\mathrm{pH}_{45} \mathrm{y} \mathrm{T}_{45}\right.$, respectively) and at $24 \mathrm{~h}$ ( $\mathrm{pH}_{24} \mathrm{y}_{24}$, respectively) postmortem using a measuring instrument of $\mathrm{pH}$ and temperature (Testo, Testo 23 model), connected to two gauges of solid and semisolid penetration. The
Las muestras de sangre se extrajeron por duplicado mediante punción de la vena yugular

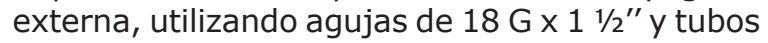
al vacío de $5 \mathrm{~mL}$ (Gel Clot Activator, Vacuum Diagnostics, Zhejiang, China). Las muestras fueron transportadas al Laboratorio de Patología Clínica de la FCV-UCV, donde el suero fue separado por centrifugación a $1.200 \mathrm{~g}$ por $20 \mathrm{~min}$ a $4^{\circ} \mathrm{C}$ dentro de las $8 \mathrm{~h}$ posteriores a su recolección y se conservaron en alícuotas de $2 \mathrm{~mL}$ a $-20^{\circ} \mathrm{C}$ hasta su análisis. Los análisis se realizaron por duplicado utilizando un kit de determinación cuantitativa cinética (Chemroy ${ }^{\circledR}$, procedimiento CR245, Texas, E.E.U.U.) y se expresó la concentración de NU en suero en $\mathrm{mg} / \mathrm{dL}$.

Evaluación de las canales. Cuando los cerdos alcanzaron el peso para el sacrificio $(102.81 \mathrm{~kg}$ en promedio), se sometieron a un periodo de ayuno de $24 \mathrm{~h}$ y se trasladaron a la planta de faenado industrial; después de $6 \mathrm{~h}$ de reposo, los cerdos se aturdieron eléctricamente y se sacrificaron mediante desangrado, de acuerdo con los procedimientos establecidos en el código de prácticas de higiene en Venezuela (18). Se registró el peso de la canal caliente (PCC, con la cabeza y las patas), se calculó el rendimiento en canal (RCC) y luego las canales se refrigeraron $\left(4-6^{\circ} \mathrm{C}\right)$ durante 16-24 h. Concluido este periodo, se retiró la cabeza y se dividió la canal longitudinalmente en dos partes iguales, permitiendo evaluar las características cuantitativas. El espesor de grasa dorsal (EGD) se midió con una regla métrica en tres ubicaciones: opuesto a la primera costilla, a la última costilla y a la última vértebra lumbar, respectivamente, obteniéndose el promedio de las tres mediciones. Se realizó un corte transversal entre el $10^{\mathrm{mo}}$ y $11^{\text {vo }}$ espacio intercostal para exponer y medir el área del músculo Longissimus dorsi (AMLD) utilizando una plantilla cuadriculada; la profundidad de la grasa dorsal (PGD) que recubre el AMLD se midió con una regla métrica, en tres posiciones (1/4, $1 / 2$, y $3 / 4$ ) del área del músculo). Los valores obtenidos del AMLD y la PGD se utilizaron para calcular el rendimiento magro de la canal (RMC) mediante ecuaciones de predicción $(6,19)$.

Las características cualitativas evaluadas en la canal fueron $\mathrm{pH}$, temperatura y capacidad de retención de agua (CRA). El pH y la temperatura de las canales se midieron en el músculo semimembranoso, a los $45 \mathrm{~min}\left(\mathrm{pH}_{45} \mathrm{y} \mathrm{T}_{45}\right.$, respectivamente) y a las $24 \mathrm{~h}\left(\mathrm{pH}_{24}\right.$ y $\mathrm{T}_{24}$, respectivamente) postmortem mediante un instrumento de medición de $\mathrm{pH}$ y temperatura (Testo, modelo Testo 23), acoplado a dos sondas de penetración de sólidos y semisólidos. La CRA se determinó de acuerdo con la metodología aplicada por Jerez-Timaure et al (20), utilizando 
WHC was determined using the methodology applied by Jerez-Timaure et al (20), using $1.6 \mathrm{~g}$ of the sample of a fresh steak obtained from the Longissimus dorsi muscle at the $10^{\text {th }}$ intercostal space. The samples were subjected to refrigerated centrifugation to obtain the percentage of water lost due to differences in weight.

Additionally, it was estimated through a frequency distribution analysis, the proportion (\%) of pale, soft and exudative meat (PSE); dry, firm and dark (DFD); and normal for each treatment, according to the classification suggested by Castrillón et al (21).

Experimental design and statistical analysis. The pigs were distributed in a randomized block design (two blocks represented by each barn) with five treatments (levels of digestible lysine), seven replications, and two pigs per experimental unit. The results were expressed as an average of weekly measurements of the DFI, DWG, FC, DLI and DLI/DWG variables of the same experimental unit. The values considered in the analysis of the ILW, FLW, UN variables and the carcass characteristics corresponded to a single measurement. The statistical analysis for all the variables was performed using the Proc Mixed of SAS software (22).

A regression analysis was used to observe the linear and quadratic effect on the levels of digestible lysine on each variable. Probability values of $p \leq 0.05$ were considered significant.

\section{RESULTS}

Under the evaluated conditions, significant differences in the productive performance were not detected in FLW, DFI, DWG and FC of the pigs due to the effect of digestible lysine levels, as is shown in table 2 . The quadratic effect of the level of digestible lysine was not significant for any of the variables, therefore only the linear effect is presented. The FLW increased linearly $(p<0.05)$ while the FC tended to decrease $(p=0.08)$ with the increase in the level of lysine in the diet. There was no evidence of the increase of DWG per unit of digestible lysine in the diet, as was expected. The DLI and the DLI/DWG varied significantly $(p<0.001)$ among treatments and increased linearly $(p<0.001)$ with the content of digestible lysine in the diet (Table 2 ). In that sense, the pigs that consumed the diet limiting in lysine $(0.46 \%)$ had less DLI $(p<0.001)$, in conjunction with the lower quantity $(p<0.001)$ required of this amino acid per kilogram of
$1.6 \mathrm{~g}$ de la muestra de un bistec fresco obtenido del músculo Longissimus dorsi a nivel del $10^{\text {mo }}$ espacio intercostal. Las muestras fueron sometidas a centrifugación refrigerada, para obtener el porcentaje de agua perdida por diferencias de peso.

Adicionalmente, se estimó mediante un análisis de distribución de frecuencia, la proporción (\%) de carnes pálidas, suaves y exudativas (PSE); secas, firmes y oscuras (DFD); y normal para cada tratamiento, de acuerdo con la clasificación sugerida por Castrillón et al (21).

Diseño experimental y análisis estadístico. Los cerdos fueron distribuidos en un diseño de bloques al azar (dos bloques representados por cada galpón) con cinco tratamientos (niveles de lisina digestible), siete repeticiones y dos cerdos por unidad experimental. Los resultados se expresan como el promedio de las mediciones semanales de las variables CDA, GDP, CA, CDLis y CDLis/GDP sobre la misma unidad experimental. Los valores considerados en el análisis de las variables PI, PVF, NU y las características de la canal correspondieron a una medición única. El análisis estadístico para todas las variables se realizó utilizando el Proc Mixed del programa SAS (22).

Se realizó un análisis de regresión para observar el efecto lineal y cuadrático de los niveles de lisina digestible sobre cada variable. Se consideraron significativos los valores de probabilidad $p \leq 0.05$.

\section{RESULTADOS}

Bajo las condiciones evaluadas, no se detectaron diferencias significativas en el desempeño productivo reflejado en el PVF, CDA, GDP y CA de los cerdos por efecto de los niveles de lisina digestible como se evidencia en la tabla 2. El efecto cuadrático del nivel de lisina digestible no fue significativo para ninguna de las variables, por lo que se presenta únicamente el efecto lineal. El PVF incrementó linealmente $(p<0.05)$ mientras que la CA tendió a disminuir $(p=0.08)$ con el incremento del nivel de lisina en la dieta. No se evidenció el incremento de la GDP por cada unidad del contenido de lisina digestible en la dieta como era de esperarse. El CDLis y la CDLis/ GDP variaron significativamente $(p<0.001)$ entre tratamientos e incrementaron linealmente $(p<0.001)$ con el contenido de lisina digestible de la dieta (Tabla 2). En tal sentido, los cerdos que consumieron la dieta limitante en lisina $(0.46 \%)$ mostraron menor CDLis $(p<0.001)$, conjuntamente con la menor cantidad $(p<0.001)$ requerida de este aminoácido por kilogramo 
Table 2. Effect of digestible lysine levels in high energy density diets on the productive performance and blood urea of finishing pigs.

\begin{tabular}{|c|c|c|c|c|c|c|c|c|}
\hline \multirow{2}{*}{ Variables } & \multicolumn{5}{|c|}{ Digestible Lysine, \% } & \multirow{2}{*}{ SE } & \multicolumn{2}{|c|}{ P value $^{f}$} \\
\hline & 0.46 & 0.52 & 0.58 & 0.64 & 0.70 & & Lysine & Linear \\
\hline ILW, $\mathrm{kg}$ & 80.22 & 83.33 & 83.22 & 84.75 & 85.29 & 1.70 & - & - \\
\hline FLW, $\mathrm{kg}$ & 99.09 & 101.66 & 103.13 & 102.83 & 106.23 & 2.29 & 0.30 & 0.03 \\
\hline DFI, $\mathrm{kg}$ & 2.95 & 2.87 & 2.89 & 2.79 & 2.98 & 0.11 & 0.80 & 0.96 \\
\hline DWG, kg & 0.90 & 0.79 & 0.92 & 0.88 & 0.97 & 0.06 & 0.35 & 0.23 \\
\hline $\mathrm{FC}, \mathrm{kg} / \mathrm{kg}$ & 3.29 & 3.61 & 3.17 & 3.15 & 3.07 & 0.19 & 0.13 & 0.08 \\
\hline DLI, g/d & $13.57^{\mathrm{a}}$ & $14.91^{\mathrm{b}}$ & $16.77^{c}$ & $=17.89^{d}$ & $20.87^{e}$ & 0.38 & $<0.001$ & $<0.001$ \\
\hline $\begin{array}{l}\text { DLI/DWG, } \\
\mathrm{g} / \mathrm{kg}\end{array}$ & $1634^{a}$ & 10 & $=18$ & b $21.78 \mathrm{c}$ & $22.44^{c}$ & 0.97 & $<0.001$ & $<0.001$ \\
\hline $\mathrm{UN}, \mathrm{mg} / \mathrm{dL}$ & 40.76 & 40.76 & 38.53 & 38.99 & 35.03 & 1.80 & 0.18 & 0.02 \\
\hline
\end{tabular}

SE: Standard error; ILW: initial live weight; FLW: final live weight; DFI: daily feed intake; DWG: daily weight gain; FC: feed conversion (DFI/DWG). The DFI, DWG and FC values correspond to the average over four weeks.

DLI: daily lysine intake; DLI/DWG: Lysine intake per $\mathrm{kg}$ of live weight gained; UN: concentration of urea nitrogen in serum.

abcde Different letters in the same row indicate significant differences according to the value of probability corresponding to the effect of the level of digestible lysine (treatment).

f Probability value corresponding to the effect of the level of digestible lysine (treatment) and the linear effect of digestible lysine as the result of the regression analysis, respectively.

weight gained, while the pigs that consumed the diet with $0.70 \%$ of digestible lysine showed the greatest DLI $(p<0.001)$. However, the DLI/DWG of the pigs fed with the diet that contained $0.52 \%$ of digestible lysine was not significantly different from that observed in the pigs whose diets contained a greater amount of lysine.

The concentration of UN (Table 2) did not significantly change among treatments but decreased linearly $(p<0.05)$ with the increase of digestible lysine in the diet.

There were not significant differences among treatments for the quantitative carcass characteristics (Table 3 ), however the BFD tended to be lower $(p=0.07)$ in the carcass of pigs whose diets contained the greatest level of lysine $(0.70 \%)$. The HCW tended to increase (linear effect, $p<0.06$ ), with the level of lysine in the diet. The qualitative carcass characteristics of the evaluated pigs did not show differences among treatments (Table 4).

The result of the frequency analysis to estimate the proportion of PSE, DFD and normal meats (Table 5) showed a greater proportion of meats with normal $\mathrm{pH}$ in the pigs fed with the experimental diets; however, within each treatment group and for the total of the samples, the percentage of meats with $\mathrm{pH}$ values below normal (PSE) oscillated between 15 and $28 \%$.
Table 3. Effect of digestible lysine levels in high energy density diets on the quantitative carcass characteristics of finishing pigs.

\begin{tabular}{|c|c|c|c|c|c|c|c|c|}
\hline \multirow{2}{*}{ Variables } & \multicolumn{5}{|c|}{ Digestible Lysine, \% } & \multirow{2}{*}{ SE } & \multicolumn{2}{|c|}{ P value ${ }^{a}$} \\
\hline & 0.46 & 0.52 & 0.58 & 0.64 & 0.70 & & Lysin & Linear \\
\hline $\mathrm{HCW}, \mathrm{kg}$ & 74.83 & 76.12 & 78.47 & 76.03 & 79.97 & 2.25 & 0.50 & 0.06 \\
\hline $\mathrm{CY}, \%$ & 75.58 & 74.91 & 75.99 & 74.62 & 75.29 & 1.12 & 0.91 & 0.96 \\
\hline $\mathrm{BFT}, \mathrm{cm}$ & 1.58 & 1.29 & 1.55 & 1.59 & 1.45 & 0.13 & 0.46 & 0.93 \\
\hline $\mathrm{BFD}, \mathrm{cm}$ & 1.27 & 0.85 & 1.13 & 1.12 & 0.90 & 0.10 & 0.07 & 0.23 \\
\hline LDMA, $\mathrm{cm}^{2}$ & 61.23 & 59.15 & 61.80 & 61.73 & 63.01 & 2.47 & 0.85 & 0.46 \\
\hline LYC, \% & 62.53 & 63.57 & 62.57 & 62.55 & 63.62 & 0.96 & 0.87 & 0.79 \\
\hline
\end{tabular}

SE: Standard error; HCW: hot carcass weight; $\mathrm{CY}$ : carcass yield; $\mathrm{BFT}$ : backfat thickness; BFD: backfat depth; LDMA: longissimus muscle area; LYC: lean yield of carcass.

a Probability value corresponding to the effect of the level of digestible lysine (treatment) and the linear effect of digestible lysine as the result of the regression analysis, respectively.

de peso ganado, mientras que los cerdos que consumieron la dieta con $0.70 \%$ de lisina digestible mostraron el mayor CDLis $(p<0.001)$. Sin embargo, el CDLis/GDP de los cerdos alimentados con la dieta que contenía $0.52 \%$ de lisina digestible no fue significativamente diferente del observado en los cerdos cuyas dietas contenían mayor cantidad de lisina.

La concentración de NU (Tabla 2) no varió significativamente entre tratamientos pero disminuyó linealmente $(p<0.05)$ con el incremento en el contenido de lisina digestible de la dieta.

No se evidenciaron diferencias significativas entre tratamientos para las características cuantitativas de la canal (Tabla 3), no obstante la PGD tendió a ser menor $(p=0.07)$ en las canales de los cerdos cuyas dietas contenían el más alto nivel de lisina $(0.70 \%)$. El PCC tendió a aumentar (efecto lineal, $\mathrm{p}<0.06)$, con el nivel de lisina en la dieta. Las características cualitativas de la canal de los cerdos evaluados no mostraron diferencias entre tratamientos (Tabla 4).

El resultado del análisis de frecuencia para estimar la proporción de carnes PSE, DFD y normal (Tabla 5), evidenció en los cerdos alimentados con las dietas experimentales, una mayor proporción de carnes con pH normal; sin embargo dentro de cada grupo de tratamiento y para el total de las muestras, el porcentaje de carnes con valores de $\mathrm{pH}$ por debajo de lo normal (PSE) osciló entre 15 y $28 \%$. 
Table 4. Effect of digestible lysine levels in high energy diets on the qualitative carcass characteristics of finishing pigs.

\begin{tabular}{|c|c|c|c|c|c|c|c|c|}
\hline \multirow{2}{*}{ Variables } & \multicolumn{5}{|c|}{ Digestible Lysine, \% } & \multirow{2}{*}{ SE } & \multicolumn{2}{|c|}{ P value ${ }^{a}$} \\
\hline & 0.46 & 0.52 & 0.58 & 0.64 & 0.70 & & Lysine & Linear \\
\hline $\mathrm{pH}_{45}$ & 6.35 & 6.13 & 6.26 & 6.32 & 6.27 & 0.09 & 0.47 & 0.89 \\
\hline $\mathrm{pH}_{24}$ & 5.71 & 5.67 & 5.60 & 5.68 & 5.63 & 0.05 & 0.60 & 0.37 \\
\hline $\mathrm{T}_{45},{ }^{\circ} \mathrm{C}$ & 36.58 & 36.12 & 37.15 & 36.81 & 36.75 & 0.53 & 0.73 & 0.59 \\
\hline $\mathrm{T}_{24}{ }^{\circ} \mathrm{C}$ & 11.11 & 11.62 & 11.59 & 11.80 & 11.44 & 0.46 & 0.86 & 0.55 \\
\hline CRA, \% & 6.21 & 6.39 & 8.46 & 5.54 & 7.40 & 0.79 & 0.11 & 0.57 \\
\hline
\end{tabular}

SE: Standard error; $\mathrm{pH}_{45}: \mathrm{pH}$ measured at 45 min postmortem; $\mathrm{pH}_{24}$ : $\mathrm{pH}$ measured at $24 \mathrm{~h}$ postmortem; $\mathrm{T}_{45}$ : temperature measured at $45 \mathrm{~min}$ postmortem; $\mathrm{T}_{24}$ : temperature measured at $24 \mathrm{~h}$ postmortem; WHC: water holding capacity, expresses the water lost by effect of centrifugation.

Probability value corresponds to the effect of the level of digestible lysine (treatment) and the lineal effect of digestible lysine as the result of regression analysis, respectively.

\section{DISCUSSION}

The results indicate that it is probable that the levels of digestible lysine evaluated were not adequate to detect the differences in the DWG, DFI, FC and FLW variables due to the treatment. Studies conducted on finishing pigs fed with deficient diets or ajusted to the lysine requirement and containing $3.4 \mathrm{Mcal} /$ $\mathrm{kg}$ of EM have also shown that there is no effect of dietary lysine level on DFI and DWG (12). Even in growing pigs, fed with lower energy density diets, the effect of lysine on the productive performance has not been observed $(3,23)$. According to those reported by several authors $(4,12,13,23,24)$, the DFI is a variable that generally is not affected by the content of lysine in the diet, response that is observed when the diets are isocaloric and the daily intake of lysine increases linearly with the content of lysine in the diet, such as in the case of the present study. Although this response was evident without significant variations in the DFI among treatments, it is indicative that the pigs do not regulate this intake in function to the amino acids present in the diet (5) but the increase of lysine intake is proportional to the content of this amino acid in it $(3,23,24)$. This argument explains the differences in DLI with each increase in the level of digestible lysine.

Previous studies have observed significant variations in DWG and FC by increasing the levels of lysine in diets with $3.6 \mathrm{Mcal} / \mathrm{kg}$ (9) and $3.48 \mathrm{Mcal} / \mathrm{kg}$ of EM (10), however, the response could be influenced by the ingredients used. Other studies $(9,10)$ used choice white grease to maintain high the energy density of the diets and increasing the content of lysine,
Table 5. Proportion (\%) of pale, soft and exudative meat (PSE), dry, firm and dark meats (DFD) and normal ones for each treatment.

\begin{tabular}{lcccccc}
\hline & \multicolumn{5}{c}{ Vigestible Lysine, \% } & \multirow{2}{*}{ Variables } \\
\cline { 2 - 6 } & $\mathbf{0 . 4 6}$ & $\mathbf{0 . 5 2}$ & $\mathbf{0 . 5 8}$ & $\mathbf{0 . 6 4}$ & $\mathbf{0 . 7 0}$ & \\
\hline $\mathrm{PSE}$, at $\mathrm{pH}_{24}$ & 15.38 & 15.38 & 28.57 & 9.09 & 25.0 & 19.05 \\
$\mathrm{DFD}$, at $\mathrm{pH}_{24}$ & 7.69 & 0 & 0 & 0 & 0 & 1.59 \\
Normal, at $\mathrm{pH} 24 \mathrm{~h}$ & 76.92 & 84.62 & 71.43 & 90.91 & 75.0 & 79.37 \\
\hline Total evaluated & 13 & 13 & 14 & 11 & 12 & 63 \\
\hline
\end{tabular}

Estimated proportion using the measurement of $\mathrm{pH}$ at $24 \mathrm{~h}\left(\mathrm{pH}_{24}\right)$ according to that suggested by Castrillón et al (21).

\section{DISCUSIón}

Los resultados indican que es probable que los niveles de lisina digestible evaluados no fueran adecuados para detectar diferencias en las variables GDP, CDA, CA y PVF por efecto de tratamiento. Estudios conducidos con cerdos en finalización alimentados con dietas deficientes o ajustadas al requerimiento de lisina y que contenían $3.4 \mathrm{Mcal} / \mathrm{kg}$ de EM, también han señalado que no hay efecto del nivel de lisina en la dieta sobre el CDA y la GDP (12). Aún en cerdos en etapa de crecimiento, alimentados con dietas de menor densidad energética, no se ha observado efecto del contenido de lisina sobre su desempeño productivo $(3,23)$. De acuerdo con lo señalado por diversos autores $(4,12,13,23,24)$, el CDA es una variable que generalmente no es afectada por el contenido de lisina en la dieta, respuesta que se evidencia cuando las dietas son isocalóricas y el consumo diario de lisina aumenta linealmente con el contenido de lisina de la dieta, tal como es el caso del presente estudio. Aunque esta respuesta se evidenció sin variaciones significativas del CDA entre tratamientos, es indicativa de que los cerdos no regulan este consumo en función de los aminoácidos presentes en la dieta (5), pero el incremento del consumo de lisina es proporcional al contenido de este aminoácido en la misma $(3,23,24)$. Argumento que permite explicar las diferencias en el CDLis con cada aumento en el nivel de lisina digestible.

Estudios previos han observado variaciones significativas en la GDP y la CA al incrementar los niveles de lisina en dietas con $3.6 \mathrm{Mcal} / \mathrm{kg}$ (9) y $3.48 \mathrm{Mcal} / \mathrm{kg}$ de EM (10), no obstante, la respuesta podría estar influenciada por los ingredientes utilizados. Otros estudios $(9,10)$ utilizaron grasa selecta para mantener alta la densidad energética 
while in the present study raw palm oil was used. This energetic ingredient, an alternative to traditional lipid sources in the tropics, can be added in a diet for finishing pigs without effects on productive performance (25).

It was observed that DLI/DWG in the diet of $0.52 \%$, corresponding to the recommended value (6), did not significantly differ from that obtained with diets that contained a greater amount of lysine. The pigs in this study consumed between 16.34 and $22.44 \mathrm{~g}$ of lysine/kg of DWG, values within the range observed in the literature for pigs of similar weight (8-10). It has also been shown that the quantity of DLI/DWG increases linearly and the DWG does not significantly change by increasing the content of lysine in the diet (4), response that also coincides with the results.

The UN concentration did not change significantly among treatments, which is explainable since the diets had similar values of crude protein. On the other hand, the regression analysis showed a linear reduction of UN with the increase of the digestible lysine levels in the diet. In that sense, it is probable that the digestible lysine levels used were very close to each other, impeding noticeable differences among treatments. It has been highlighted that the quantity of lysine consumed is used for maintenance and protein deposition (6), after which it is catabolized and the resulting nitrogen is excreted as urea. The excess of amino acids in the diet has been related to high UN concentrations (26) and therefore the concentration of urea in blood is an indicator of protein metabolism. In this study the concentration of UN decreased linearly, which indicates that there was no excess of amino acids. Respecting the results obtained in the UN, other studies $(24,26)$ have not observed differences among treatments by increasing the levels of digestible lysine in the diet.

Referring to the quantitative carcass characteristics, although there was a linear trend of HCW to increase with the lysine content, overall no significant differences were observed among treatments. This result indicates that the increase of HCW was associated to the simultaneous increase of the FLW. According to the results of the current study, increasing the levels of digestible lysine in the diet does not affect the quantitative carcass characteristics of finishing pigs $(8,24)$ nor have significant effects been detected when changing the nutritional plan by adjusting those levels in the diets on carcass yield or lean carcass yield (5). de las dietas e incrementando el contenido de lisina, mientras que en el presente estudio se utilizó aceite crudo de palma. Este ingrediente energético alternativo a las fuentes lipidicas tradicionales en el trópico, puede ser incluido en la dieta para cerdos en finalización sin efectos sobre el comportamiento productivo (25).

Se observó que el CDLis/GDP en la dieta de $0.52 \%$, correspondiente al valor recomendado (6), no difirió significativamente de la obtenida con las dietas que contenían mayor cantidad de lisina. Los cerdos del presente estudio consumieron entre 16.34 y $22.44 \mathrm{~g}$ de lisina/kg de GDP, valores que se ubicaron dentro del rango observado en la literatura para cerdos de peso similar (8-10).También se ha demostrado que la cantidad de CDLis/GDP aumenta linealmente y la GDP no varía significativamente al incrementar el contenido de lisina en la dieta (4), respuesta que también coincide con los resultados expuestos.

La concentración de NU no varió significativamente entre tratamientos, lo cual es explicable ya que las dietas mantuvieron valores semejantes de proteína cruda. Por otra parte, el análisis de regresión evidenció la disminución lineal de NU con el incremento en los niveles de lisina digestible en la dieta. En tal sentido, es probable que los niveles de lisina digestible utilizados fueran muy cercanos entre sí, impidiendo evidenciar diferencias entre tratamientos. Se ha señalado que la cantidad de lisina consumida es utilizada para cubrir las necesidades de mantenimiento y deposición de proteína (6), luego de lo cual es catabolizada y el nitrógeno resultante de ese catabolismo es excretado como urea. El exceso de aminoácidos en la dieta, se ha relacionado con altas concentraciones de NU (26) por lo que la concentración de urea en sangre es un indicador del metabolismo proteico. Debido a que en el presente estudio la concentración de NU disminuyó linealmente, indica que no existió exceso de aminoácidos. Con respecto a los resultados obtenidos en la NU, otros estudios $(24,26)$ no han observado diferencias entre tratamientos al incrementar los niveles de lisina digestible en la dieta.

Referente a las características cuantitativas de la canal, aunque se observó una tendencia lineal del PCC a aumentar con el contenido de lisina,de manera general,no se observaron diferencias significativas entre tratamientos para estas características. Este resultado indica que el aumento en el PCC estuvo asociado al aumento simultáneo del PVF. De acuerdo con los resultados del presente estudio, se ha evidenciado que el incremento de los niveles de lisina digestible en la dieta no afecta las características cuantitativas de la canal de cerdos en etapa de finalización $(8,24)$, así como tampoco 
Regarding the qualitative carcass characteristics of finishing pigs fed with different levels of lysine, it has been shown that characteristics such as $\mathrm{pH}(2,3,12)$ and $\mathrm{WHC}(2)$ are not affected. It has been noted $(3,24)$ that carcass characteristics vary little in response to variations in the content of lysine in the diet, which may be attributed in this study to the fact that the feed intake was similar among different treatments and when experimental diets were formulated, a similar energy density was maintained, and the digestible amino acid requirements were considered. Moreover, these aspects also explain the invariable response in the productive performance of the pigs evaluated.

With respect to the frequency distribution analysis to estimate the proportion of PSE, DFD and normal meat, there was greater proportion of meat with normal $\mathrm{pH}$ in all the carcass evaluated. Lysine levels in the diet did not affect the $\mathrm{pH}$ or temperature of the carcass, so that the occurrence of PSE meat can be attributed to chronic stress just before slaughter (27) or the handling of pigs, especially while stunning (20).

The PSE meat is a defect associated with a rapid rate of postmortem glycolysis, which is characterized by a high acidification rate in the meat; while DFD meats are due to prolonged stress that consumes the reserves of muscular glycogen before slaughter, resulting in a low production of lactic acid (1). Studies in Mexico have found a proportion of PSE pork meat between 3.5 and $8.0 \%$ (1), while in Venezuela values between 8 and $10 \%$ have been observed, and a greater percentage of meats with $\mathrm{pH}_{24}$ values that have oscillated between 5.5 and 6.0 (20). However, the proportion of PSE meats was lower when compared with that shown in this study, while the $\mathrm{pH}_{24}$ values are slightly lower than those observed in the country (15). According to Castrillón et al (21), for pork meat, values of $\mathrm{pH}_{24} \leq 5.5$ indicate PSE meats; values of $\mathrm{pH}_{24} \geq 6.0$, are considered DFD meats, while values between 5.6 and 5.9 indicate normal meats. The proportion of normal meat was close to that obtained by Alarcón et al (1), although inferior to that observed in a study in Venezuela (20).

The results allow to conclude that the levels of digestible lysine between 0.46 and $0.70 \%$ in diets with $3.5 \mathrm{Mcal} / \mathrm{kg}$ of ME do not affect the productive performance and carcass characteristics of finishing pigs. However, the amount of lysine consumed per unit of weight gained increased with the level of digestible lysine in the diet. se han detectado efectos significativos al variar el plano nutricional ajustando estos niveles en las dietas, sobre el rendimiento en canal o rendimiento magro de la canal (5).

Con respecto a las características cualitativas de la canal de cerdos alimentados en la etapa de finalización con diferentes niveles de lisina, se ha demostrado que las características como $\mathrm{pH}$ $(2,3,12)$ y CRA $(2)$ no se afectan. Se ha señalado $(3,24)$ que las características de la canal varían poco en respuesta a variaciones en el contenido de lisina en la dieta, lo que puede atribuirse en el presente estudio, a que los cerdos mostraron un consumo de alimento semejante en los distintos tratamientos, y al formular las dietas experimentales se mantuvo similar la densidad energética de la dieta y se consideraron las necesidades de aminoácidos digestibles. Además, estos aspectos también permiten explicar la respuesta sin variaciones en el desempeño productivo de los cerdos evaluados.

Con respecto al análisis de distribución de frecuencia para estimar la proporción de carnes PSE, DFD y normal, existió mayor proporción de carnes con pH normal en todas las canales evaluadas. Los niveles de lisina en la dieta no afectaron el $\mathrm{pH}$ ni la temperatura de las canales, por lo que la ocurrencia de carnes PSE puede atribuirse al estrés crónico justo antes del beneficio (27) o al manejo de los cerdos, principalmente durante el aturdimiento (20).

La carne PSE es un defecto asociado con una tasa rápida de glicólisis post-mortem, la cual se caracteriza por una alta tasa de acidificación de la carne; mientras que las carnes DFD se debe a un estrés prologando que consume las reservas de glucógeno muscular antes del sacrificio, resultando en escasa producción de ácido láctico (1). Estudios en México, han encontrado una proporción de carne de cerdo PSE entre 3.5 y $8.0 \%$ (1), mientras que en Venezuela se han observado valores entre 8 y $10 \%$ y mayor porcentaje de carnes con valores de $\mathrm{pH}_{24}$ que han oscilado entre 5.5 y 6.0 (20). No obstante, la proporción de carnes PSE fue menor al compararse con la evidenciada en el presente estudio, mientras que los valores de $\mathrm{pH}_{24}$ son ligeramente más bajos a los observados en el país (15). Según Castrillón et al (21), para carne de cerdo, valores de $\mathrm{pH}_{24} \leq 5.5$ indican, carnes PSE; valores de $\mathrm{pH}_{24} \geq 6.0$, se consideran carnes DFD, mientras que valores entre 5.6 y 5.9 indican carnes normales. La proporción de carnes normales se aproximó a la obtenida por Alarcón et al (1), aunque inferior a la observada en un estudio de Venezuela (20).

Los resultados permiten concluir que los niveles de lisina digestible entre 0.46 y $0.70 \%$ en dietas 
The linear increase of final live weight per unit of lysine was noted without the concomitant increase in weight gain, and without differences among treatments, which may be associated with the fact that lysine levels evaluated were not wide enough each other to detect it. In this regard, conducting further studies to evaluate digestible lysine levels of greater amplitude at various levels of metabolizable energy is recommended.

\section{Acknowledgments}

To the Council of Scientific and Humanistic Development of the Universidad Central de Venezuela (Proyect-PG-11-8192-2011/1). To Crisna Tovar, Assistant of the Laboratory of Clinical Pathology of the FCV-UCV and Franklin Mora, Swine Section of the Agronomy FacultyUCV, for the support given in the laboratory and experimental activities, respectively. con $3.5 \mathrm{Mcal} / \mathrm{kg}$ de EM no afectan el desempeño productivo y las características de la canal de los cerdos en etapa de finalización. No obstante, la cantidad de lisina consumida por unidad de peso ganado aumenta con el nivel de lisina digestible en la dieta.

El incremento lineal del peso vivo final por cada unidad del contenido de lisina se evidenció sin el concomitante aumento en la ganancia de peso, y sin diferencias entre tratamientos lo que podría asociarse a que los niveles de lisina evaluados no fueron lo suficientemente amplios entre sí para detectarlas. En tal sentido, se recomienda la realización de nuevos estudios dirigidos a evaluar niveles de lisina digestible de mayor amplitud a varios niveles de energía metabolizable.

\section{Agradecimientos}

Al Consejo de Desarrollo Científico y Humanístico de la Universidad Central de Venezuela (ProyectoPG-11-8192-2011/1). A Crisna Tovar, Asistente del Laboratorio de Patología Clínica de la FCV-UCV y al Ing. Franklin Mora de la Sección Porcinos de La Facultad de Agronomía-UCV, por su apoyo en las actividades de laboratorio y campo, respectivamente.

\section{REFERENCIAS}

1. Alarcón AD, Duarte JO, Rodríguez FA, Janacua H. 2005. Incidencia de carne pálida, suave y exudativa (PSE) y oscura-firme-seca (DFD) en cerdos sacrificados en la región del Bajío en México. Téc Pecu Méx 2005; 43(3):335-346.

2. Cho SB, Han IK, Kim YY, Park SK, Hwang OH, Choi CW, et al. Effect of lysine to digestible energy ratio on growth performance and carcass characteristics in finishing pigs. AsianAust J Anim Sci 2012; 25:1582-1587.

3. Fortes EI, Donzele JL, Oliveira RFM, Saraiva A, Oliveira RFM, Oliveira FCS, et al. Digestible lysine for 63 to 103 day-old barrows of genetic lines selected for lean deposition. R Bras Zootec 2011; 40(10):2167-2171.

4. Nemechek JE, Gaines AM, Tokach MD, Allee GL, Goodband RD, DeRouchey JM, et al. Evaluation of standardized ileal digestible lysine requirement of nursery pigs from seven to fourteen kilograms. J Anim Sci 2012; 90:4380-4390.
5. Corassa A, Kiefer C, Gonçalves LMP. Planos nutricionais de lisina para suínos da fase inicial a terminação. Arch Zootec 2013; 62:533-542.

6. National Research Council. Nutrient Requirements of Swine. 10th ed. Washington DC, USA: National Academy Press. NRC;1998.

7. Schneider JD, Tokach MD, Dritz SS,J. L. Nelssen, DeRouchey JM, Goodband RD. Determining the effect of lysine:calorie ratio on growth performance of ten to twenty kilogram of body weight nursery pigs of two different genotypes. J Anim Sci 2010; 88:137-146.

8. De La Llata M, Dritz SS, Tokach MD, Goodband RD, Nelssen JL. Effects of increasing lysine to calorie ratio and added fat for growingfinishing pigs reared in a commercial environment: I. Growth performance and carcass characteristics. Prof Anim Scientist 2007; 23:417-428. 
9. Main RG, Dritz SS, Tokach MD, Goodband RD, Nelssen JL. Determining an optimum lysine:calorie ratio for barrows and gilts in a commercial finishing facility. J Anim Sci 2008; 86:2190-2207.

10. Shelton NW, Tokach MD, Dritz SS, Goodband RD, Nelssen JL, DeRouchey JM. Effects of increasing dietary standardized ileal digestible lysine for gilts grown in a commercial finishing environment. J Anim Sci 2011;89:3587-3595.

11. Li P, Zheng Z, Wang D, Xue L, Zhang R, Piao $X$. Effects of the standardized ileal digestible lysine to metabolizable energy ratio on performance and carcass characteristics of growing-finishing pigs. J Anim Sci Biotechnol 2012; 3:1-9.

12. Jin $\mathrm{YH}$, Oh HK, Piao LG, Jang SK, Choi YH, Heo PS, et al. Effect of dietary lysine restriction and energy density on performance, nutrient digestibility and meat quality in finishing pigs. Asian-Aust J Anim Sci 2010; 23(9): 1213-1220.

13. Zhang J, Yin J, Zhou X, Li F, Ni J, Dong B. Effect of lower dietary lysine and energy content on carcass characteristics and meat quality in growing finishing pigs. Asian-Aust J Anim Sci 2008; 21(12):1785-1793.

14. González D. González C, Machado W, Mendoza J, Ly J. Jugo de caña de azúcar en dietas de crecimiento y finalización para cerdos: efectos en el comportamiento productivo y rasgos de canal. Rev Cientif FCV-LUZ 2006; 16(4):406-413.

15. Flores-Rondón C, Leal-Ramírez M, RodasGonzález A, Aranguren-Méndez J, RománBravo R, Ruiz-Ramírez J. Efecto de la condición sexual y pesos al sacrificio sobre las características de la canal y la calidad de la carne de cerdo. Rev Cientif FCV-LUZ 2009; 19(2):165-172.

16. Association of Official Analytical Chemists. Official Methods of Analysis.16th ed. Arlington, VA, USA: AOAC; 1995.

17. Ministerio del Poder Popular para Ciencia, Tecnología e Industrias Intermedias y Fondo Nacional de Ciencia, Tecnología e Innovación. Código de Bioética y Bioseguridad. $3^{a}$ ed. Caracas, Venezuela: MPPCT-FONACIT; 2008.
18. Comisión Venezolana de Normas Industriales. Código de prácticas de higiene para mataderos industriales, frigoríficos industriales y salas de matanza municipales o privadas. Caracas, Venezuela: COVENIN;1986 Norma Venezolana:794-86.

19. National Pork Producers Council. Pork Composition and Quality Assessment procedures. Des Moines, IA, USA: NPPC; 2000.

20. Jerez-Timaure N, Sulbarán MT, Arenas de Moreno L, Rodas-González A,Trompiz J, Ortega J. Determinación de defectos de calidad en la canal y carne de cerdo mediante el uso de auditorías. Rev Mex Cienc Pecu 2013; 4(1):13-30.

21. Castrillón WE, Fernández JA, Restrepo LF. Variables asociadas con la presentación de carne PSE (Pálida, Suave, Exudativa) en canales de cerdo. Rev Colomb Cienc Pecu 2007; 20:327-338.

22. SAS Institute Inc. Statistical Analysis System, SAS 9.1, Cary, NC, USA: SAS Institute; 2004.

23. Haese D, Donzele JL, Oliveira RFM, Saraiva A, Oliveira FCS, Kill JL, et al. Digestible lysine for barrows of genetic lines selected for meat deposition from 60 to 100 days of age. R Bras Zootec 2011; 40(9):1941-1946.

24. Abreu MLT, Donzele JL, Oliveira RFM, Oliveira ALS, Santos F, Pereira AA. Níveis de lisina digestível em rações, utilizando-se o conceito de protein ideal, para suínos machos castrados de alto potencial genético para deposição de carne magra na carcaça dos 60 aos $95 \mathrm{~kg}$. R Bras Zootec 2007;36(1):54-61.

25. Terán G, Sarmiento L, Segura J, Torres F, Santos R. Comportamiento productivo, características de la canal y peso del tracto gastrointestinal de cerdos alimentados con aceite de palma africana (Elaeis guineensis). Téc Pecu Méx 2004; 42(2):181-192.

26. López M, Figueroa JL, González MJ, Miranda LA, Zamora V; Cordero JL. Niveles de lisina y treonina digestible en dietas sorgo-pasta de soya para cerdos en crecimiento. Arch Zootec 2010; 59(226):205-216.

27. Hambrecht E, Eissen JJ, Newman DJ, Smits CHM, den Hartog LA, Verstegen MWA. Negative effects of stress immediately before slaughter on pork quality are aggravated by suboptimal transport and lairage conditions. J Anim Sci 2005; 83:440-448. 